\title{
The Scalp Involvements in the Connective Tissue Diseases
}

\author{
Niang Suzanne Oumou, Coumé Mamadou ${ }^{2}$, Ndiaye Maodo ${ }^{1}$, Diop Assane ${ }^{1}$, Diatta Boubacar Ahy ${ }^{1}$, \\ Diallo Moussa $^{1}$, Dieng Mame Thierno ${ }^{1}$, Kane Assane ${ }^{1}$
}

${ }^{1}$ Service de Dermatologie, Hôpital A. Le Dantec, Dakar, Senegal; ²Clinique Médicale I, Hôpital A. Le Dantec, Dakar, Senegal. Email: suzeoumou@yahoo.com

Received June $14^{\text {th }}, 2011$; revised July $5^{\text {th }}, 2011$; accepted July $14^{\text {th }}, 2011$.

\begin{abstract}
Background: The involvements of the scalp over the connective tissue diseases (lupus, sclerodermia and dermatomyositis) are often the present complaint due to the disfigurement they cause. The aim of our study was to identify the various involvements of the scalp over the connective tissue diseases. Method: We conducted a descriptive study over a period of seven months of every instance of involvement of the scalp and hair during connective tissue diseases received in the department. A tensile test, a Trichogram and mycological sampling were performed. Results: 25/35 involvements of the scalp were noted (71.42\%); all of them were female and the mean age was 32 years. It was a lupus in 17 cases, sclerodermia in 6 cases, dermatomyositis and a sclerodermatomyositis. They were the present complaint in $48 \%$ of cases within 3 years and preceding the other lesions in 32\% of cases. We noted fragile and dry hair in 10 cases, straightened hair in 8 cases and hypochromic spots fleck in 5 cases. Conclusion: Connective tissue diseases cause severe injuries and often reveal a risk of permanent cicaticial alopecia and fungal superinfection. The cicatricial alopecia and straightened hair are secondary to immune disorders.
\end{abstract}

Keywords: Scalp, Connectivite, Senegal

\section{Introduction}

Integumentary manifestations are important in the connective tissue diseases (lupus, scleroderma and dermatomyositis) [1]. They not only enable early diagnosis, but permit a rapid intervention that avoids the occurrence of mutivisceral complications.

Skin sclerosis, muscle weakness and osteoarticular damage, weaken the functional prognosis [2,3]. Scalp manifestations, because of the visible aesthetic changes they cause, frequently push the patients to seek medical advice. The purpose of this study is to identify the different scalp manifestations in the connective tissue disorders.

\section{Patients and Methods}

We conducted a prospective descriptive study from October 2009 to April 2010 in the Department of Dermatology in the Hospital Aristide Le Dantec. It is the largest referral center for Dermatology in Senegal.

In this study were included, all the patients diagnosed with connective tissue diseases, (lupus, scleroderma and dermatomyositis) who had scalp lesions.
A tensile test, a trichogram and mycological sampling were performed.

After taking the history of the present illness, the hair was examined and its fragility was assessed by a tensile test, a trichogram was done so is the mycologic sampling was done in case of squames.

The tensile test was positive if 1 to 2 hairs break after traction of 10 hairs. The principle of trichogram is to extract 50 hairs and examine the roots between slides under the microscope at a magnification of 20.The quantification allowed us to conclude, to a dystrophic formula if the percentage of dystrophic hair was over $20 \%$, and to a telogen formula, if it was over $14 \%$ and finally mixed if it's increased for the dystrophic and anagens. After an appropriate topical and systemic treatment of the connective tissue diseases (corticosteroids, antimalarials, penicillamine $\mathrm{D}$ ) and of the fungal infections if necessary, a monthly monitoring was conducted.

\section{Results}

We identified 35 cases of connective tissue diseases over a period of 7 months divided as follow: 23 cases of lupus (discoid lupus in 8 cases and systemic lupus in 15 cases), 
10 cases of scleroderma, 1 case of dermatomyositis and 1 case of sclerodermatomyositis. They were distributed among 32 women and 3 men. The mean age was 35 years with extremes of 15 and 65 years old.

Among the 35 cases, 25 (71.42\%) had scalp involvement. All were females with a mean age of 32 years. There were 17 cases of lupus (68\%), 6 cases of systemic scleroderma, 1 case of dermatomyositis, and 1 case of sclerodermatomyositis.

The scalp lesions were the chief complaint in 12 cases (48\%) with a mean first visit time interval of 3 years with extremes between 7 and 10 years.

The scalp and hair lesions were concomitant to the other integumentary lesions in 15 cases (60\%), anterior in 8 cases (32\%) and posterior in 2 cases. The distribution of cases by abnormalities of hair is illustrated in Table 1. These abnormalities have led to cicatricial alopecia (Figure 1) in 10 cases (8 cases of discoid lupus and 2 cases of systemic sclerosis), a non-cicatricial alopecia (Figure 2) in 14 cases ( 9 cases of lupus, 4 cases of scleroderma, 1 case of sclerodermatomyositis). The hair was fragile and dry in 10 cases (40\%). It was a lupus in 6 cases, a scleroderma (Figure 3 ) in 3 cases and a sclerodermatomyositis in 1 case. Silky hair was noted in 8 cases (32\%) involving 6 cases of systemic lupus (Figure 4), 1 case of scleroderma and 1 case of dermatomyositis.

The tensile test positive in 15 cases (60\%) was observed in 6 cases of lupus and 2 cases of scleroderma. An abnormal trichogram was noted in 21 cases, it showed a telogen formula in 11 cases, a dystrophic formula in 6 cases and a mixed formula one in 4 cases. Scalp lesions showed alopecia in 20 cases (80\%), characteristic lesions of connective tissue diseases in 16 cases and to tinea capitis in 4 cases. The mycological sampling isolated Trichophyton soudanense in 2 cases, Trichophyton rubrum and Microsporum andouini in 1 case each. The alopecia was cicatricial in 10 cases $(40 \%), 8$ cases of lupus and 2 cases of scleroderma.

Table 1. Distribution of abnormalities in connective tissue diseases.

\begin{tabular}{cccccc}
\hline & $\mathrm{a}$ & $\mathrm{b}$ & $\mathrm{c}$ & $\mathrm{d}$ & Total \\
\hline Silky hair & 6 & 1 & & & 7 \\
Broken hair and dryness of the hair & 8 & 4 & 1 & 1 & 14 \\
Tinea capitis & 2 & 2 & & 4 \\
Atrophic erythematous plaque & 8 & 0 & & 8 \\
Sclerous plaque & & 2 & & 2 \\
Hypochromic lesions & & 4 & & 4 \\
Erythemato squamous lesions & 2 & & & 2 \\
\hline
\end{tabular}

a: Lupus; b: Scleroderma; c: Dermatomyositis; d: Sclerodermatomiositis.



Figure 1. Cicatricial alopecia in discoid lupus.

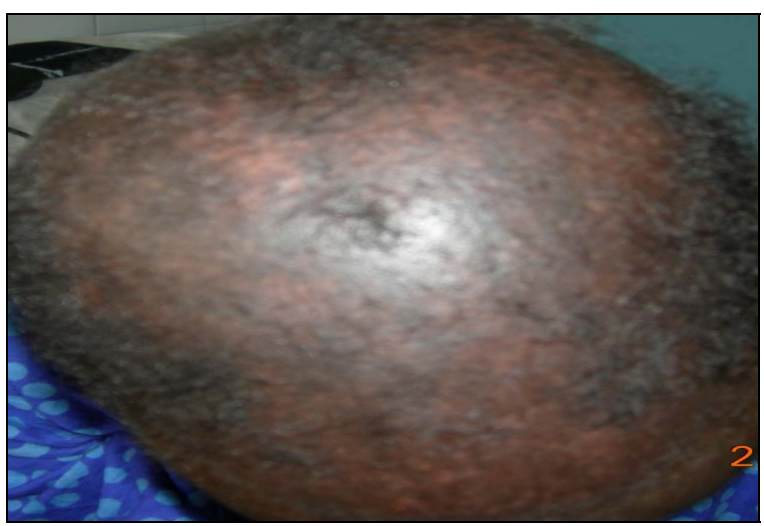

Figure 2. Non-cicatricial alopecia in lupus.



Figure 3. Hypochromic lesions and tinea capitis in scleroderma. 


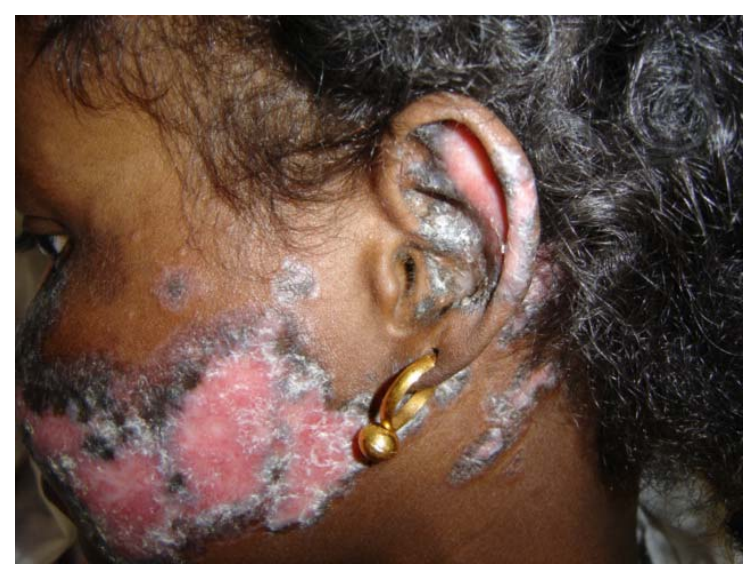

Figure 4. Silky hair in lupus.

\section{Discussion}

Our study has confirmed the frequent involvement of the scalp in the connective tissue diseases, tinea capitis, cicatricial alopecia and the visible aesthetic changes allowed the discovery of the connective tissue diseases in one third of the cases. The frequency in our study (71.42\%) was even higher than the one noted in Ndiaye's study [4]. Among 38 cases of connective tissue diseases (21 scleroderma, 9 systemic lupus, 3 dermatomyositis and 5 mixed connective), tinea capitis was noted in 15 cases. The scaly lesions of tinea may look like the lesions of erythemato-squamous lupus. The mycological sampling confirms the diagnosis of tinea capitis.

The mean age of onset and female predominance was similar to the other studies [5-8].

The predilection of these involvements in lupus is linked to the prevalence of lupus in the others connective tissue diseases in our department. The delay of the first medical visit and the diagnosis is explained by the low socio-economic status, poor education and illiteracy. Aesthetic changes caused by the lesions of the scalp justified the consultation in nearly half of cases and they preceded the other lesions of connective tissue diseases in $1 / 3$ of the cases and may be the first clue of diagnosis. Discoid lupus is the primary lesion of the scalp (47\%). Its frequency varies from 40 to $50 \%$ in other series [9]. Tang found 7/12 cases of involvement of the scalp [10], and Degos in his cohort of 248 patients with Lupus has found $22.5 \%$. Like the sclerous plaques of scleroderma, it causes permanent cicatricial alopecia. Discoid lupus is a pre-neoplastic lesion and can be responsible for epidermoid carcinoma [11,12].

The localization on the scalp aggravated by photoexposition, can be an additional promoting factor of transformation into epidermoid carcinoma [13]. In our study, we did not note any case of epidermoid carcinoma.

Wearing a traditional scarf to hide these lesions is an effective manner of photoprotection. The non-cicatricial alopecia indicating a broken hair [14] is demonstrated by the positivity of the tensile test and the telogen formula of Trichogram. The anticipation of the hair growth cycle leading to telogen effluvium is secondary to immune disturbance noted in the connective tissue diseases. The silky hair, delicate dry hair and tinea capitis underline immunosuppression as seen in HIV infection. The presence of tinea capitis in the connective tissue diseases has been reported in lupus [15-17]. In Ndiaye's study, it was reported in $39.47 \%$ of cases [4]. They are sometimes a main symptom leading to the diagnosis of connective tissue disorders but can be confused with erythematous and squamous lesions specific to the lupus. The mycological sampling takes on its full value.

\section{Conclusions}

The involvement of the scalp can be the circumstance of discovery in the connective tissue diseases. They can lead to a risk of cicatricial alopecia. An early treatment should be instituted.

\section{REFERENCES}

[1] B. Weill and I. Cochin, "Diagnostic des Connectivites," Arthritis Rheum, Vol. 50, 2004, pp. 3418-3426.

[2] C. Francès, "Lupus Érythémateux,” In: D. Bessis, Eds., Manifestations Dermatologiques des Connectivites. Vasculites et Affections Systémiques Apparentées, Springer, Paris, 2007, pp. 1-18.

[3] D. Dia and M. Dieng, "Aspects Cliniques de la Sclérodermie Systémique du Noir Africain au Sénégal,” La Revue de Médecine Interne, Vol. 24, Supplement 4, 2003, p. 378. doi:10.1016/S0248-8663(03)80327-2

[4] B. Ndiaye, M. Develoux, M. T. Dieng and O. Ndir, "Fréquence des Teignes chez les Patients Atteints de Connectivites à Dakar (Sénégal),” Journal de Mycologie Médicale, Vol. 5, No. 4, 1995, pp. 239-243.

[5] P. Humbert and E. Puzenat, "Sclérodermie Systémique et Sclérodermies Cutanées,” In: D. Bessis, Manifestations Dermatologiques des Connectivites. Vasculites et Affections Systémiques Apparentées, Springer, Paris, 2007, pp. 3-12.

[6] M. M. Ka, S. Diallo, A. Kane, et al., "Lupus Érythémateux Systémique au Sénégal,” Médecine d'Afrique Noire, 1998, pp. 41-45.

[7] B. Louzir, S. Outhmani, N. Ben Abdelhafidh, "Le Lupus Érythémateux Systémique en Tunisie: Étude Multicentrique Nationale: À Propos de 295 Observations,” La Revue de Médecine Interne, Vol. 24, No. 12, 2003, pp. 768-774. doi:10.1016/S0248-8663(03)00250-9

[8] S. Outmani and B. Louzir, “Le Groupe d’Étude du Lupus. Lupus Systémique chez 24 Hommes Tunisiens: Analyse Clinico-Biologique et Évolutive,” La Revue de Médecine Interne, Vol. 23, 2002, pp. 983-990. 
[9] D. Bonvalet, “Les Alopécies Cicatricielles,” In: P. Bouhanna and P. Reygagne, Eds., Pathologie du Cheveu et du Cuir Chevelu, Masson, Paris, 1999, pp. 172-184.

[10] W. Y. M. Tang, L. Y. Chan and K. K. Lo, "Discoid Lupus Erythematosus in Hong Kong Chinese: A Review of 12 Cases," Hong Kong Medical Journal, Vol. 2, No. 3, 1996, pp. 239-246.

[11] J. H. Saurat, P. Musette, D. Lipsker, "Signes Cutanés du Lupus Érythémateux,” In: J. H. Saurat, E. Grosshans, P. Laugier, J. M. Lachapelle, Eds., Dermatologie et Infections Sexuellement Transmissibles, 4ème Édition, Masson, Paris, 2004, pp. 349-352.

[12] M. T. Dieng, N. N. Diop, A. Dème, T. N. Sy, S. O. Niang and B. Ndiaye, "Carcinome Épidermoïde sur Peau Noire: 80 Cas,” Annales de Dermatologie et de Vénéréologie, 2004, Vol. 131, No. 12, pp. 1055-1057. doi:10.1016/S0151-9638(04)93840-9

[13] M. T. Dieng and A. Ndiaye, "Carcinome Épidermoide sur Lupus Érythemateux Discoide (Trois Observations),” Da- kar Médical, Vol. 46, 2001, pp. 73-75.

[14] P. Burch and N. Rowell, "Lupus Erythematosus. Analysis of the Sex and Age. Distributions of the Discoid and Systemic Forms of the Disease in Different Countries," Acta Dermato-Venereologica, Vol. 50, 1970, pp. 293-300.

[15] A. Kane, D. Ndiaye, S. O. Niang, F. Ly, O. Ndir and B. Ndiaye, "Tinea in Senegal: an epidemiology study," International Journal of Dermatology, Vol. 44, No. 1, 2005, pp. 24-25. doi:10.1111/j.1365-4632.2005.02804.x

[16] A. M. Deloul, D. Dompmartin and J. P. Coulaud, “A Propos de 39 Cas de Teignes du Cuir Chevelu Observes à Paris dans Une Consultation de Médicine Tropicale,” Bull Soc Path ex, Vol. 78, 1985, pp. 37-42.

[17] M. J. Stiller, S. A. Rosenthal and A. S. Weinstein, “Tinea Capitis Caused by Trichophyton Rubrum in a 67 Hears Old Woman with Systemic Lupus Erythematous,” Journal of the American Academy of Dermatology, Vol. 29, No. 2, 1993, pp. 257-258. doi:10.1016/S0190-9622(08)81842-7 